Supporting Information for

\title{
Macromolecular crowding and confinement effect on the growth of DNA nanotubes in Dextran and hyaluronic acid media
}

Qiufen Zhang ${ }^{1}$,Qingwen Bai, ${ }^{1}$ Lin Zhu ${ }^{1}$,Tianhao Hou ${ }^{2}$, Jiang Zhao ${ }^{2 *}$, Dehai Liangl*

${ }^{1}$ Beijing National Laboratory for Molecular Sciences, Department of Polymer Science and Engineering and the Key Laboratory of Polymer Chemistry and Physics of the Ministry of Education, College of Chemistry and Molecular Engineering, Peking University, Beijing 100871, China

E-mail: dliang@pku.edu.cn

${ }^{2}$ Beijing National Laboratory for Molecular Sciences, Institute of Chemistry, Chinese Academy of Sciences, Beijing 100190, China.

E-mail: jzhao@iccas.ac.cn 


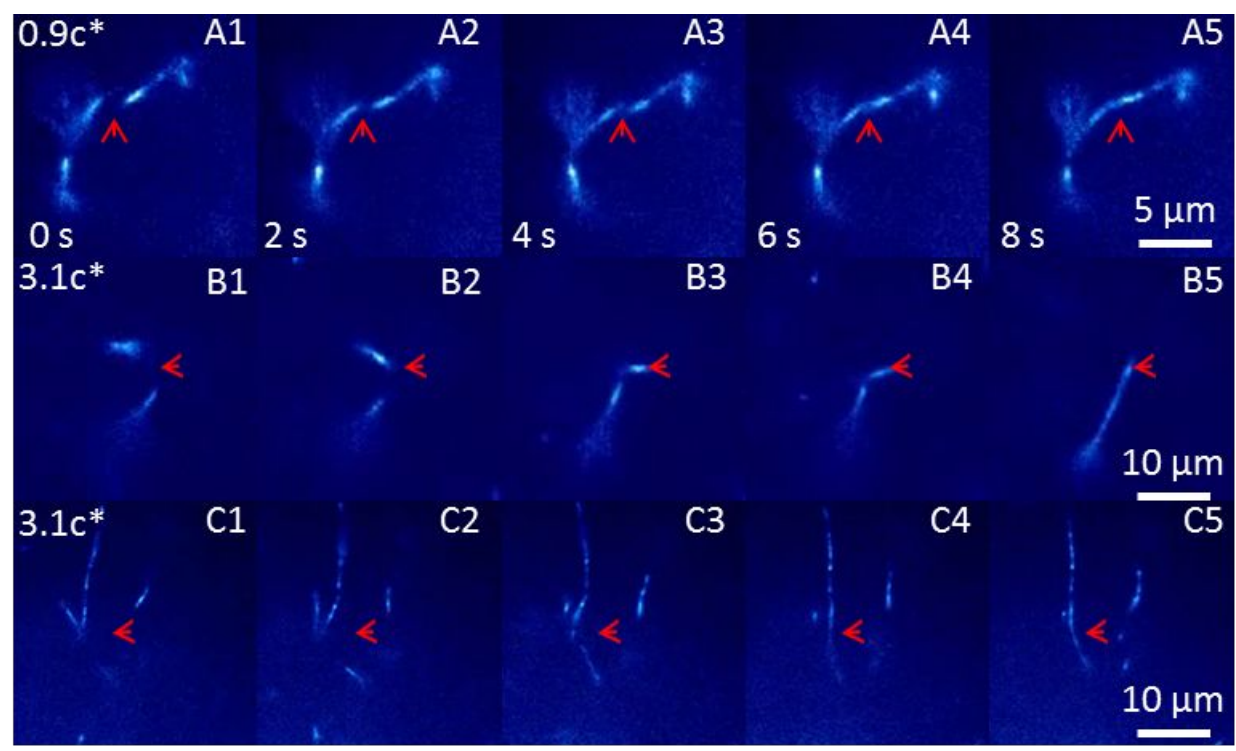

Fig S1: End-end connection of long DNA nanotubes in (A1-A5) $60.0 \mathrm{mg} / \mathrm{mL}$ Dextran solution with $150 \mathrm{mM} \mathrm{NaCl}$, (B1-B5) $60.0 \mathrm{mg} / \mathrm{mL}$ Dextran solution without $\mathrm{NaCl}$, (C1-C5) $200 \mathrm{mg} / \mathrm{mL}$ Dextran solution without $\mathrm{NaCl}$. The time points of the images from left to right are $0,2,4,6$, and $8 \mathrm{~s}$.

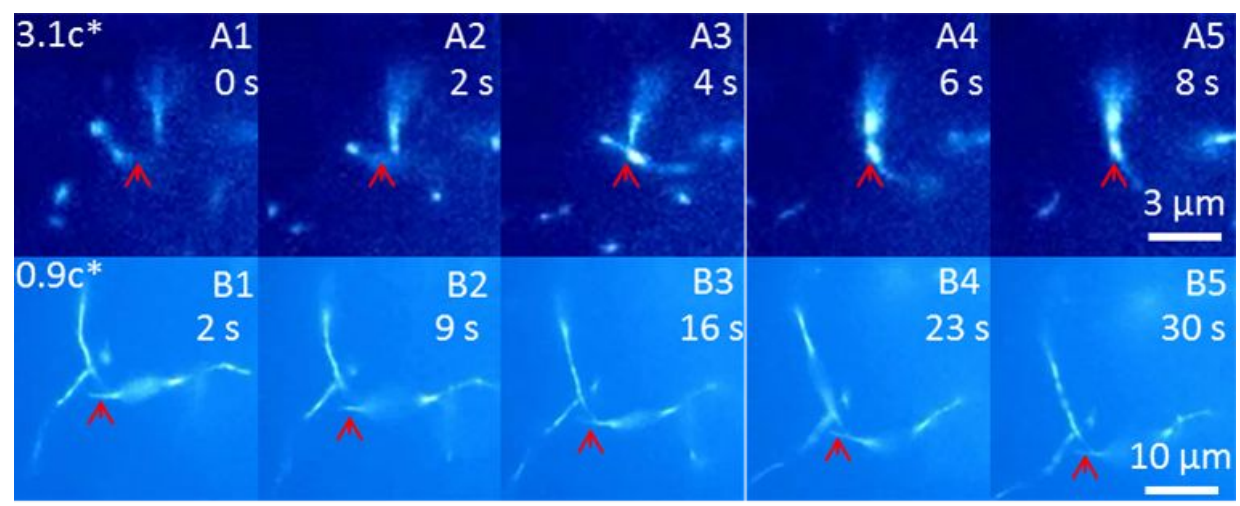

Fig S2: The side-end connection of DNA nanotubes in (A1-A5) $0 \mathrm{NaCl}, 210.0 \mathrm{mg} / \mathrm{mL}$ Dextran medium and (B1-B5) $150 \mathrm{mM} \mathrm{NaCl}, 60.0 \mathrm{mg} / \mathrm{mL}$ Dextran medium. The time points are labeled in each panel. 

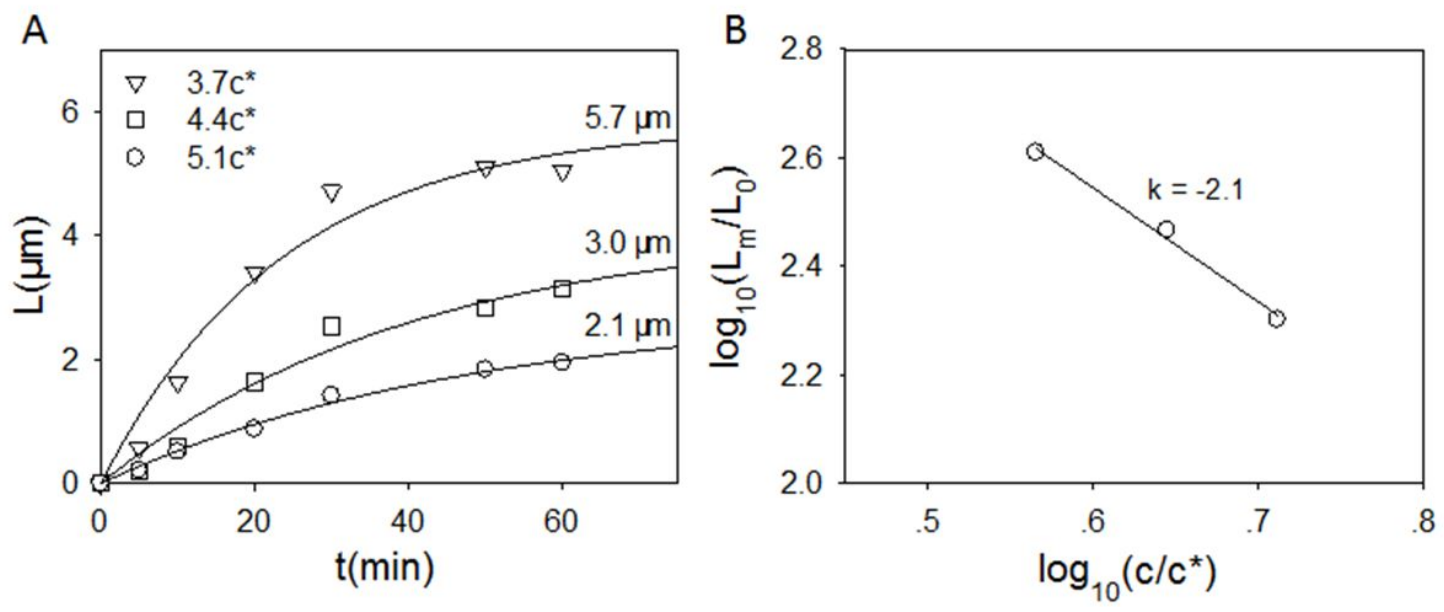

Figure S3: Growth curves of DNA nanotubes in the confinement regime in Dextran solution with $150 \mathrm{mM} \mathrm{NaCl}(A)$, and the dependence of $\mathrm{L}_{\mathrm{m}} / \mathrm{L}_{0}$ on $\mathrm{c} / \mathrm{c}^{*}(\mathrm{~B}) . \mathrm{L}_{\mathrm{m}}$ values at each concentration and the slope are marked. 

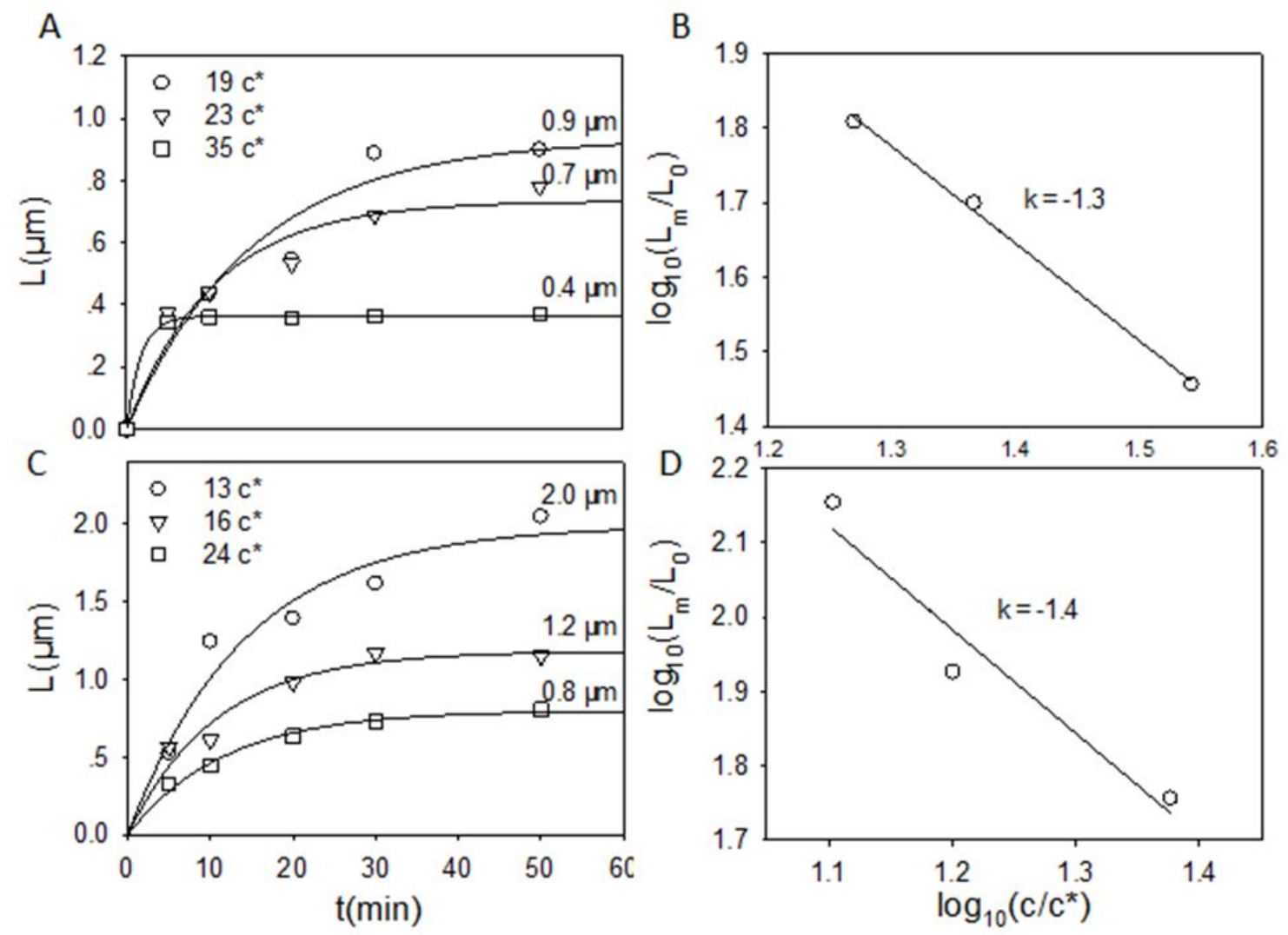

Figure S4: Growth curves of DNA nanotubes $(A, C)$ and the dependence of $\mathrm{L}_{\mathrm{m}} / \mathrm{L}_{0}$ on $\mathrm{c} / \mathrm{c}^{*}(\mathrm{~B}, \mathrm{D})$ in the confining regime in HA without $(\mathrm{A}, \mathrm{B})$ and with $150 \mathrm{mM} \mathrm{NaCl}$ solution $(C, D) . L_{m}$ values at each concentration and the slopes are marked.

Table S1: Equilibrium length and initial growth rate of DNA nanotubes in the confinement regime in Dextran solution without $\mathrm{NaCl}$

\begin{tabular}{|c|c|c|c|c|}
\hline $\mathrm{C}_{\text {Dextran }} / \mathrm{c}^{*}$ & 2.8 & 3.1 & 3.8 & 4.6 \\
\hline $\mathrm{L}_{\mathrm{m}} / \mu \mathrm{m}$ & 7.4 & 5.0 & 3.4 & 2.5 \\
\hline $\mathrm{V}_{\mathrm{ini}} /\left(\mu \mathrm{m} \cdot \mathrm{min}^{-1}\right)$ & 0.18 & 0.28 & 0.27 & 0.28 \\
\hline
\end{tabular}


Table S2: Equilibrium length and initial growth rate of DNA nanotubes in the confinement regime in $\mathrm{HA}$ solution without $\mathrm{NaCl}$

\begin{tabular}{|c|c|c|c|}
\hline $\mathrm{c}_{\mathrm{HA}} / \mathrm{c}^{*}$ & 19 & 23 & 35 \\
\hline $\mathrm{L}_{\mathrm{m}} / \mu \mathrm{m}$ & 0.9 & 0.7 & 0.4 \\
\hline $\mathrm{V}_{\mathrm{ini}} /\left(\mu \mathrm{m} \cdot \mathrm{min}^{-1}\right)$ & 0.058 & 0.067 & 0.24 \\
\hline
\end{tabular}

